Suzana Marković* Srđan Mitrovic ${ }^{* *}$ Aleksandar Racz, ${ }^{* * *}$
JEL Classification M0, M3, C1, C4 Preliminary statement https://doi.org/10.32910/ep.70.2.3

\title{
WHO ARE THE WINE AND FOOD FESTIVAL VISITORS? AN EXPLORATORY STUDY
}

Hosting wine festivals provides the opportunity to organizers and wine destinations to offer a wide range of experiences that differ from the day-today way of life and, in a sense, are the best way to provide a wine tourism lifestyle experience. The aim of the research was to measure the wine and food personality traits of festival visitors, specifically involvement and neophobia, and explore their relationship with the experience quality dimensions of the festival (environment, education, service providers, functional benefits, entertainment) and experience outcomes (satisfaction, loyalty). Additionally, research aimed to compare wine and food involvement and neophobia with regard to specific demographic characteristics of the visitors (gender, income level, visitor status, employment, residency). Data collection was done during the VinoCOM festival on $24^{\text {th }}$ and $25^{\text {th }}$ November 2017 in Zagreb using an on-site questionnaire. Descriptive and bivariate statistical analyses were used to analyze collected data. The results obtained show a significant and positive relationship between wine and food involvement and experience

* S. Marković, PhD, Full Professor, University of Rijeka, Faculty of Tourism and Hospitality Management, Opatija, Croatia (E-mail: suzanam@fthm.hr).

${ }^{* *}$ S. Mitrović, PhD student, University of Rijeka, Faculty of Tourism and Hospitality Management, Opatija, Croatia (E-mail: mitrovic.srdan@gmail.com).

*** A. Racz, PhD, Assistant Professor and PhD student, University of Applied Health Sciences, Zagreb, University of Rijeka, Faculty of Tourism and Hospitality management, Opatija, Croatia (E-mail: aracz@zvu.hr).

The paper was received on June 19th, 2018. It was accepted for publication on October 22nd, 2018. 
quality as well as experience outcomes. At the same time it is confirmed a negative relationship between wine and food neophobia, experience quality and experience outcomes.

Key words: wine tourism, wine festival, experience quality, festival visitors, festival visitor satisfaction

\section{Introduction}

Since the mid-1990s wine tourism has become an important form of tourism with an evident growth in tourists interested in wine but the definition and conceptualization of "wine tourism" has not resulted in a uniform approach (Getz and Brown 2006). Hall et al. (2000) defined wine tourism as "visitation to vineyards, wineries, wine festivals and wine shows for which grape wine tasting and/or experiencing the attributes of a grape wine region are the prime motivating factors for visitors" however, Getz (2000) claims that there are multiple perspectives on the subject i.e. that of the wine producers, that of the agency and that of the tourist so we can observe wine tourism as a form of consumer behavior, a strategy by which destinations develop and market wine-related attractions and imagery, and a marketing opportunity for wineries to educate, and to sell their products, directly to consumers (Getz and Brown 2006). Just as any other consumers in today's fastgrowing world of the experience economy, wine consumers are in search of products and services that have both utilitarian and hedonic components (Sandstorm, Edvardsson, Kristensson and Magnusson, 2008). Berry, Carbone and Haeckel (2002) have argued that businesses should strive to provide meaningful experiences to their customers to add value to their core product or service. According to Charters and Ali-Knight (2002) and Galloway, Mitchell, Getz, Crouch, and Ong (2008), the best way to provide wine tourism experiences is through hosting festivals and events. Wine festivals have been defined as special occasions in which visitors actively engage for the satisfaction of their interest in wine and/or for the entertainment made available by other leisure activities (Yuan, Cai, Morrison and Linton, 2005). Furthermore, festivals provide opportunities to raise awareness of both wineries and destinations (Taylor and Shanka, 2007) as well as to increase revenue flows with direct sales at the festival and create relationships with consumers that can lead to long term sales and generate brand loyalty (Treloar and Hall, 2008).

Cohen and Avieli (2004) have suggested that neophilic tendencies and high food involvement are displayed by tourists who take gastronomic tours and who tend to be more inclined to new food experiences due to their wine and food re- 
lated personality traits. Events and festivals, based around wine and food as a form of wine or food tourism, usually play an important role in introducing a tourist to new flavors and different traditions during their visit to a destination (Getz 2000; Hjalager and Corigliano, 2000; Yuan et al., 2005). Food and wine festivals also present visitors with an authentic lifestyle experience in a pleasant environment (Getz, 2000).

Kim, Knutson and Beck (2011) claim that research from the perspective of food-related personality traits is still relatively young and that the integration of the two bodies of hospitality and tourism events and food choice research is almost never seen. Therefore, this research aims to measure food related personality traits of the visitors, namely wine and food involvement and neophobia, and compare them in regard to their demographic characteristics as well as explore the relationship between food related personality traits and perceptions of experience quality and experience outcomes of the festival. This paper should give us better insight into the specific food related personality traits of the wine and food festival visitors and clarify in what extent, if at all, they influence the visitors' perception of experience quality and their satisfaction and loyalty as experience outcomes.

The paper is organized as follows. First, a literature review is provided regarding the main research constructs. Next, research methodology is explained, together with the research results. The final section describes the paper's theoretical and managerial contribution as well as the limitations of the study.

\section{Literature review}

\subsection{Consumer experience}

Pine and Gilmore (1998) have argued that after a shift from selling products to selling services, the next market shift is going to be towards selling experiences. They pointed out that consumers' needs for unique experiences should be met by businesses in all industries, including tourism, by delivering memorable experiences. Experiences have been viewed as the nature of the tourism industry in many studies (Cohen, 1979; Sternberg, 1997; Quan and Wang, 2004; Uriely, 2005), while the most important part of the tourism experience according to Stamboulis and Skayannis (2003) is visiting, seeing, learning, enjoying and living a different life in a different environment. Pine and Gilmore (1999) claimed that experience can be analyzed though consumers' connectedness with the experience, where consumers can immerse themselves in the experience or simply absorb it, and 
through their participation in the experience, where they can be active and affect the experience themselves or remain passive and not influence the nature of the experience. They developed a framework of four realms of experience, namely education, entertainment, esthetic and escape (4Es), which depend on the form of consumer involvement in the experience. Education experiences are viewed as a combination of consumers' active participation and absorption, where consumers are enhancing their knowledge or skills through active participation of the mind and the body and by absorbing events that are unfolding before them (Oh, Fiore and Jeoung 2007). Entertainment experiences require that the offerings catch and occupy the customers' attention and readiness, as a combination of passive participation and absorption, in which the participant passively absorbs what is happening (Mehmetoglu, Engen 2011). Esthetic experiences are seen as a combination of immersion and passive participation but with a greater depth and immersion with respect to what is seen or experienced, without affecting or altering the nature of the environment presented to them. In addition, they are influenced by the way the surrounding environment appeals to their senses (Mehmetoglu, Engen 2011, Oh, Fiore and Jeoung 2007). Escapist experiences, as a combination of immersion and active participation, require greater immersion and participation. Consumers participating in escapist experiences do not just embark from but also voyage to a specific place and participate in activities worthy of their time (Pine and Gilmore 1999). In general, these experiences are a way for people to escape from their daily life and return to the routine after experiencing the extraordinary (Oh, Fiore, Jeoung 2007). Additional to Pine and Gilmore's four realms of experience quality, much research has been devoted to understanding the role of the employee in the delivery of experience (Slatten et al., 2009).

Service employees have the potential to influence the value-creating experience by interacting with the customer (Sandstrom et al., 2008; Walls 2013) and can play a crucial part in the quality of the consumer experience (Fernandes 2016). Finally, the experience dimension of functional benefits reflects practical or functional experience outcomes, such as performance, consistency, and customization/adaptability (Knutson et al., 2007). The experience should fit the purpose for which it was designed in an efficient, convenient and hassle-free manner (Kim et al., 2011), and this applies to tourist experiences as well (Volo, 2009).

Recently, "customer experience" has become a key concept in service research and management in fields such as services marketing, innovation and retailing (Jakkola, Helkkula and Aarikka-Stenroos, 2015). The "experience economy" concept suggests that experience can be seen as a form of economic offering creating a competitive advantage that is hard to imitate or replace. Researchers have recently found that the consumer experience has to be viewed as a multidimensional evaluation in which multiple factors contribute to form a holistic view (Schmitt, 
1999; Gentile, Spiller and Noci, 2007; Kim et al., 2011), but the dimensions of the consumer experience concept can be hard to separate, challenging to orchestrate and beyond the control of the provider of goods or services. Consequently, it has been underlined by many researchers that the creation of "extraordinary" customer experiences is necessary as a part of the strategy to bring value to the consumer and foster satisfaction, loyalty and positive word of mouth. (Pine and Gilmore, 1998; Berry et al., 2002; Shaw and Ivens, 2005; Backstrom and Johansson, 2006; Naylor, Keiser, Baker and Yorktown, 2008; Bolton et al 2014).

\subsection{Experience and its consequences}

A well-staged experience shapes tourists' attitudinal evaluation, such as satisfaction and future intentions (Oh et al., 2007; Walls, 2013). Satisfaction is considered a judgment from the consumer whether the selected alternative has met or exceeded expectations (Oliver, 1997) and in the case of experiences satisfaction is usually conceptualized as a function of whether visitors' expectations or their psychological needs are met (Han et al., 2009). Customer satisfaction is also known as an emotional response to direct product experiences (Han and Back, 2007; Bagdare and Jain, 2013). Pine and Gilmore (1999) noted that the 4Es lead to satisfaction; Oh et al. (2007) found a significant relationship between esthetic experience and satisfaction; and Hosany and Witham (2010) showed that only two of the $4 \mathrm{Es}$, esthetics and entertainment, significantly contribute to satisfaction. Loyalty is defined as repeat purchasing behavior and can manifest in repurchase intentions, spreading positive word of mouth or recommendations (Lee, Bruwer and Song, 2015). Creating memorable customer experiences is the key to driving word-ofmouth (Kenningham et al., 2007; Tung and Ritchie, 2011) and loyalty (Lemke et al., 2011; Manthiou et al., 2014). According to Naylor et al. (2008) and Frow and Payne (2007), delivering memorable customer experiences can be an opportunity to promote customer advocacy and foster customer satisfaction and loyalty.

\subsection{Wine tourism experience}

Wine tourism experiences can be offered in many ways such as visiting vineyards, wineries and wine festivals (Bruwer, 2003), which can, according to Axelsen and Swan (2010), provide a wide range of experiences that differ from day-to-day living and could be viewed as a possible lifestyle tourism experience (Gross and Brown, 2006). 
Wine tourism activities include all four realms of experience suggested by Pine and Gilmore $(1998,1999)$. Wine tourism programs, in the form of winery visits, tastings or festivals, involve an esthetic experience. Because most wine regions are isolated natural environments, away from metropolitan cities, it can be argued that the cultural, environmental and human improvements of the landscape in vinicultural areas reflect the esthetic motivation of the tourist. Such programs are also connected to the escapist experience where tourists passively appreciate the wine culture and natural environments and are motivated by serenity and calm, in contrast to their regular working lives where speed and efficiency are priorities. It is the disparity of place that draws urbanites to the rural tourism experience and signifies the escapist realm (Bruwer, 2003; Urry, 1995). According to Quadrri and Fiore (2013), wine destinations provide numerous activities in which the tourist may be actively involved, ranging from hot air ballooning and bicycle tours to grape stomping and harvesting. These participatory activities have been noted as reasons for visiting wine destinations (Fountain and Charters, 2010; Sparks, 2007). With regard to the educational dimension, most wine tourism experiences consist of a series of opportunities for tourists to learn about the grapes, terroir and history of the region and has repeatedly been revealed as a motivation in wine tourism research literature (Charters and Ali-Knight, 2000; Fountain and Charters, 2010; Getz and Carlsen, 2008). The realm of entertainment experiences is obvious in the active enjoyment of wine, cuisine and other offerings of the wine growing area (Lee et al., 2015) but it is intensely felt in the context of special events organized in wine destinations. Research has shown that events within wine destinations are a considerable draw for tourists (Carmichael, 2005; Williams and Kelly, 2001) and may augment tourists' entertainment experience.

Additionally, Fernandes (2016) expanded the four realms of wine tourism experience to include new dimensions: the dimension of functional benefits, which focuses more on the practical or functional aspects of a wine tourism experience such as buying wine at cellar prices or special offers at wine festivals, and the dimension of service providers, which focuses on service employees at wineries or festivals who can play a crucial role in the delivery and quality of a visitor's experience. According to De Rojas and Camarero (2008), a complete tourism experience includes social interaction, education and leisure. While tourists visit destinations to have memorable experiences they visit wine festivals or partake in other activities of wine tourism to have a wine experience as well as other leisure related experiences (Steyn, Saayman and Nienaber, 2004). The diversity of the wine festival experience is reflected in its opportunity to offer interactivity, leisure, social and cultural experiences (Taylor and Shanka, 2007; Axelsen and Swan, 2010) while Getz and Carlsen (2008) suggest that escape-seeking wine tourists need entertaining presentations of educational activities for a positive experience. 


\subsection{Hypothesis development}

The connection between food-related personality traits and consumer behavior has been researched from various perspectives by scholars. Khan (1981) argued that food choice, at an individual level, is determined by factors linked to several factors, including people's interrelated aspects of personality and the environment in which they lived, while Ajzen (1991) claimed that personality traits play an integral role in establishing personal choice criteria through the values held by the consumer and can be used to predict their behavior. Factors such as sensory perception, monetary consideration, convenience, health benefits or quality can also be associated with consumers' purchase behavior, as can different food-related personality traits such as food adventurousness (Furst, Connors, Bisogni, Sobal and Falk, 1996).

The extent to which consumers will be reluctant to try novel foods, recipes or cuisines is defined as food neophobia (Pilner and Hobden, 1992). The inclination towards new food experiences is displayed by consumers with a low level of food neophobia, as those types of consumers often have a different taste physiology and are able to experience new tastes and taste sensations with more enjoyment. The food neophobia scale was developed by Pilner and Hobden (1992) and has since been used to analyze consumers' perception of certain types of food and determine the general tendency toward novel foods (Arvola, Lahteenmaki and Tuorila, 1999; Raudenbush and Frank 1999; Ritchey, Frank, Hursti and Tuorila, 2003; Tuorila, Meiselman, Bell, Cardello and Johnson, 1994). It has been shown that neophobia is an accurate predictor of consumers' tendency towards novel foods. Food neophobia was found to be a factor that influences the initial tasting of food. Continued consumption is determined by other factors (Arvola et al., 1999). Raudenbush and Frank (1999) found that food neophobics also had different expectations about unfamiliar food that also shaped their rating of the food and subsequent behavior. The food neophobia scale was also tested in a cross-national comparison by Ritchey et al. (2003) who empirically proved that the food neophobia scale accurately predicts responses to novel foods across different national samples.

Closely connected to food neophobia is food involvement, defined as the level of importance of food in a person's life, measuring how much certain people enjoy talking about food, thinking about food or partaking in food related activities. It has been found to influence brand loyalty, product information search processing, responses to advertising communications, diffusion of innovations and, ultimately, product choice decisions (Bell and Marshall, 2003). Highly involved consumers are more likely to be open to new food experiences and the desire for new experiences increases the importance of food in their lives (Kim et al, 2010). Regardless of how one accounts for differences in food involvement, in all cases the sensation 
and pleasure associated with the eating experience assume more importance for an individual who is high in food involvement than for one who is low (Bell and Marshall, 2003). The role of involvement is usually essential in predicting tourist behaviors (Bruwer and Buller, 2013). Whereas Ajzen (1991) discussed the possible uses for involvement as a part of a Theory of Planned Behavior, Sparks (2007) concluded that involvement with wine tends to affect attitude towards wine experiences.

Food related personality traits research in the context of wine and food festivals is at a relatively early stage of integration (Kim, Won and Eves 2010) as only a few studies have so far in some way combined the concepts of food and wine related personality traits and experiences, experience outcomes, behaviors and attitudes toward the festival. Cohen and Avieli (2004) researched the attraction of food and beverages in tourism and consider food neophobic tendencies an outstanding element, as eating involves actual bodily involvement. Getz and Brown (2006) concluded that consumers' involvement with wine is likely to be a determinant of wine-related travel. Gross and Brown (2006) found that the dimension of food and wine involvement was an indicator of lifestyle tourism experiences. Sparks (2007) found that directly and indirectly food and wine involvement has an effect on intentions to participate in a wine-based holiday. Kim, Eves and Scarles (2009) identified three important elements influencing the consumption of local food in a destination: physiological factors (food neophilia, neophobia), motivational factors (exciting experience, escape from routine) and demographic factors, and suggested that engagement with local food or wine in the destination may be driven by food related personality traits such as food neophilia or neophobia. In sum, involvement has been researched as an antecedent and determinant of motivation, attitude and lifestyle, but no study has, according to the authors' knowledge, explored the relationship between wine and food personality traits and visitors experience within Pine and Gilmore's conceptualized 4Es experience economy framework.

We argue that personal perception of wine tourism experiences, in the context of wine festivals, is based on personal food and wine preferences (food and wine neophobia) and the level of food and wine interests (food and wine involvement), and will be closely correlated to a wine festival visitor's evaluation of the festival experience (Barber, Taylor and Deale 2010). Accordingly, the following hypotheses are proposed:

- H1: Wine and food involvement has a positive, significant relationship with experience quality

o Hla Wine and food involvement has a positive, significant relationship with education experience

o HIb Wine and food involvement has a positive, significant relationship with environment experience 
o Hlc Wine and food involvement has a positive, significant relationship with service providers experience

o HId Wine and food involvement has a positive, significant relationship with functional benefits experience

o Hle Wine and food involvement has a positive, significant relationship with entertainment experience

- H2: Wine and food neophobia has a negative, significant relationship with experience quality

o H2a Wine and food neophobia has a negative, significant relationship with education experience

o $H 2 b$ Wine and food neophobia has a negative, significant relationship with environment experience

o H2c Wine and food neophobia has a negative, significant relationship with service providers experience

o H2d Wine and food neophobia has a negative, significant relationship with functional benefits experience

o H2e Wine and food neophobia has a positive, significant relationship with entertainment experience

Kim, Won and Eves (2010) found that food neophobia and food involvement can be added as one of the considerable factors influencing experience, satisfaction and loyalty in hospitality and tourism and, consequently, that food-related personality traits associated with food experiences should result in significant relationships with satisfaction and loyalty. In that regard, the wine experience and involvement with wine can be important predictors of the decision-making process of the wine tourist (Getz and Brown, 2006). Lu, Chi and Liu (2015) claim that high involvement in tourism events such as wine festival activities significantly influences tourists' travel experiences. Similarly, increased tourist involvement in local activities directly improves tourist satisfaction, so we can argue that a higher involvement level of the wine festival visitor will lead to greater satisfaction with the festival (Poria et al., 2004). Based on these previous studies, it is assumed that experience and involvement have an impact on attitude toward future behavior with regard to wine tourism experiences and the following hypotheses are proposed:

- H3: Wine and food involvement has a positive, significant relationship with experience outcomes

o H3a Wine and food involvement has a negative, significant relationship with satisfaction

o H3b Wine and food involvement has a negative, significant relationship with loyalty 
- H4: Wine and food neophobia has a negative and significant relationship with experience outcomes

o H4a Wine and food neophobia has a negative, significant relationship with satisfaction

o H4b Wine and food neophobia has a negative, significant relationship with loyalty

According to the work of Kim, Eves and Scarles (2009), consumption of local food is influenced by involvement with food but also by demographics. In addition, Brown, Havitz and Getz (2006) claim there are multiple levels and segments of wine involvement that are influenced by consumer demographics, so the following hypotheses are proposed:

o H5: There is a significant difference in the level of wine and food involvement with regard to wine festival visitors' demographic characteristics

o H5a There is a significant difference in the level of wine and food involvement with regard to wine festival visitors' gender

o H5b There is a significant difference in the level of wine and food involvement with regard to wine festival visitors' status

o H5c There is a significant difference in the level of wine and food involvement with regard to wine festival visitors' income

o H5d There is a significant difference in the level of wine and food involvement with regard to wine festival visitors' employment

$o$ H5e There is a significant difference in the level of wine and food involvement with regard to wine festival visitors' residency

o H6: There is a significant difference in the level of wine and food neophobia with regard to wine festival visitors' demographic characteristics

o H6a There is a significant difference in the level of wine and food neophobia with regard to wine festival visitors' gender

o H6b There is a significant difference in the level of wine and food neophobia with regard to wine festival visitors' status

o H6c There is a significant difference in the level of wine and food neophobia with regard to wine festival visitors' income

o H6d There is a significant difference in the level of wine and food neophobia with regard to wine festival visitors' employment

o H6e There is a significant difference in the level of wine and food neophobia with regard to wine festival visitors' residency 


\section{Research methodology}

\subsection{Research objectives}

The aim of the research was to measure wine and food personality traits of festival visitors, specifically involvement and neophobia, and explore their relationship with experience quality dimensions of the festival (environment, education, service providers, functional benefits, entertainment) and experience outcomes (satisfaction, loyalty). Additionally, the research aimed to compare wine and food involvement and neophobia with regard to specific demographic characteristics of the visitors (gender, income level, visitor status, employment, residency).

\subsection{Research instrument}

The research instrument was divided into five parts, with four parts focusing on the main research constructs of wine and food involvement, wine and food neophobia, experience quality, experience outcomes, and the fifth part referring to the demographic characteristics of the visitors. For measuring each construct, with the exception of entertainment experience, multi-item scales were drawn from previous literature and adapted to the wine and food festival context of the research.

An adapted Food Neophobia Scale (Pilner and Hobden, 1992; Ritchey et al., 2003) was used to measure wine and food neophobia, while wine and food involvement was measured with the adopted Food Involvement Scale (Bell and Marshall, 2003).

Experience outcomes (satisfaction, loyalty) were measured with items adopted from Kim et al. (2010) while items measuring environment experience where adopted from the work of Chang and Horng (2010) and the Consumer Experience Index model (Kim et al., 2011) which was also used for items in the functional benefits experience construct. Service providers experience items were drawn from the work of Chang and Horng, (2010) and the Experience Quality scale (Klaus and Maklan, 2012). Entertainment and education experience items were adopted from Chang and Horng (2010). 
Table 1 .

\section{EXPERIENCE QUALITY AND WINE AND FOOD PERSONALITY TRAITS DIMENSIONS}

\begin{tabular}{|l|l|}
\hline Dimensions & Researchers \\
\hline Environment & Chang and Horng, (2010); Kim et al., (2011) \\
\hline Service Providers & Chang and Horng, (2010); Klaus and Maklan, (2012) \\
\hline Learning & Chang and Horng, (2010); Fernandes, (2016) \\
\hline Entertainment & Fernandes, (2016) \\
\hline Functional Benefits & Kim et al., (2011) \\
\hline Loyalty & Kim et al., (2010) \\
\hline Advocacy & Kim et al., (2010) \\
\hline Satisfaction & Kim et al., (2010) \\
\hline Wine/Food neophobia & Pilner and Hobden, (1992.); Ritchey et al., (2003.); Kim et al., (2010.) \\
\hline Wine/Food involvement & Bell and Marshall, (2003.); Kim et al., (2010.) \\
\hline
\end{tabular}

All items regarding wine and food involvement and neophobia, experience quality and experience outcomes were measured on a 7-point Likert scale, ranging from "strongly disagree" to "strongly agree". It is important to note that the food neophobia construct was reverse scored so high scores point to a low level of wine and food neophobia.

The last part of the research instrument was designed to collect demographic characteristics of the festival visitors which included: gender, age, client status, income, education, residency, marital status, employment and accommodation.

\subsection{Data collection procedure}

Collection of data on wine and food festival visitors was done using an onsite survey during VinoCOM, an international wine and food festival, that was held at the Esplanade hotel in Zagreb on the $24^{\text {th }}$ and $25^{\text {th }}$ of November 2017.

The VinoCOM wine and food festival is held every year in late November at Hotel Regent Esplanade in Zagreb over the span of two days, almost exclusively on Friday and Saturday, with both exhibitors and visitors paying an admission fee. While it was originally conceived as a trade fair to connect the supply and demand of Croatia's blossoming wine industry, it has grown into an almost lifestyle event where a great number of lovers of food and wine in the region visit yearly to taste 
the newest releases and artisan products of premium Croatian and international producers, along with numerous trade visitors who cover all aspects of the food and wine industry, from winemakers and distributors, to restaurants and sommeliers. In 2017, approx. 300 exhibitors and 7000 visitors were present at the festival.

Questionnaires were distributed by six college students experienced in polling who instructed the visitors on the purpose of the research and who were placed in locations within the festival where visitors would come to relax after tasting and talking with the exhibitors. The purpose of handing out paperback questionnaires in the lounge areas of the festival was to capture the full attention of the visitor, at least for the several minutes it took to fill out the form. Each questionnaire was inspected on the spot by the students and additional feedback on any missing data was requested directly from the visitors.

\subsection{Data analysis}

Data were analyzed using the Statistical Package for Social Sciences v23 on Windows 10. Descriptive and bivariate statistical analyses were conducted to examine and describe the data. Specifically, independent sample $t$ tests were performed to determine the significance of differences in the mean scores of each construct regarding the selected demographic characteristics of the festival visitors, and Pearson's

correlation coefficient was used to determine the relationship between wine and food neophobia, involvement, experience quality constructs and outcomes.

\section{Research results}

\subsection{Visitors profile}

The sample consisted of 304 respondents, fairly evenly divided between residents of the area (46,7\%), non-residents (53.3\%) and between female (54.8\%) and male (45.2\%) visitors. Most of the respondents were domestic (84.2\%). About half of the visitors $(56.9 \%)$ were single, while most visitors where currently employed (77.7\%), belonged to the average or higher income level bracket (84.8\%), and their educational level was mostly at the college level or above (66.5\%). There were more return visitors (64.8\%) than first-time visitors (36.2\%). The approximate average age of the visitors was 33 . 
Table 2.

SOCIO-DEMOGRAPHIC CHARACTERISTICS OF RESPONDENTS (N = 304)

\begin{tabular}{|c|c|c|c|}
\hline \multirow{2}{*}{\multicolumn{2}{|c|}{ Variables and characteristics }} & \multicolumn{2}{|c|}{ Respondents } \\
\hline & & \multirow{2}{*}{$\begin{array}{c}\text { Frequency } \\
256\end{array}$} & \multirow{2}{*}{$\begin{array}{c}\text { Percentage } \\
84.2\end{array}$} \\
\hline & Croatia & & \\
\hline Country & Other & 48 & 15.8 \\
\hline \multirow{5}{*}{ Age } & $<20$ & 7 & 2.3 \\
\hline & $20-30$ & 137 & 45.1 \\
\hline & $30-40$ & 91 & 29.9 \\
\hline & $40-50$ & 45 & 14.8 \\
\hline & $>50$ & 24 & 7.9 \\
\hline \multirow{2}{*}{ Sex } & Male & 137 & 45.2 \\
\hline & Female & 166 & 54.8 \\
\hline \multirow{2}{*}{ Marital Status } & Married & 131 & 43.1 \\
\hline & Single & 173 & 56.9 \\
\hline \multirow{2}{*}{ Visitor Status } & First-Time Visitor & 107 & 35.2 \\
\hline & Return Visitor & 197 & 64.8 \\
\hline \multirow{2}{*}{ Residency } & Local resident & 142 & 46.7 \\
\hline & Non-resident & 162 & 53.3 \\
\hline \multirow{5}{*}{ Employment } & Employed & 189 & 62.2 \\
\hline & Self-employed & 47 & 15.5 \\
\hline & Retired & 6 & 2.0 \\
\hline & Unemployed & 13 & 4.3 \\
\hline & Other (student etc.) & 49 & 16.1 \\
\hline \multirow{3}{*}{ Education } & High School & 102 & 33.5 \\
\hline & College/University & 196 & 64.5 \\
\hline & Post-Graduate & 6 & 2.0 \\
\hline \multirow{3}{*}{ Income } & Higher than average & 121 & 39.8 \\
\hline & Average & 137 & 45.0 \\
\hline & Lower than average & 46 & 15.2 \\
\hline
\end{tabular}

Source: Research results

\section{Comparison of visitors' wine and food personality traits with selected demographic characteristics of the visitors}

The next section contains the results of descriptive and bivariate statistical analysis. Table 3 reports the significance of differences in mean scores between first-time and return visitors and visitors with average or higher, or below average, income level with regard to their wine and food personality traits. 


\begin{tabular}{|c|c|c|c|c|c|c|c|c|c|c|c|c|c|c|c|}
\hline \multirow{8}{*}{ 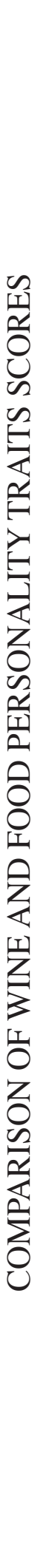 } & \multirow{3}{*}{ 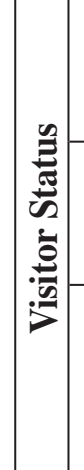 } & \multirow{2}{*}{ 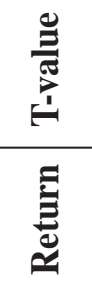 } & \multirow{2}{*}{ 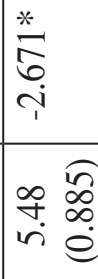 } & \multicolumn{2}{|l|}{$\begin{array}{l}\infty \\
\infty \\
\infty \\
\dot{1}\end{array}$} & 茫 & \multirow{2}{*}{ 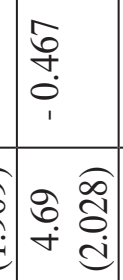 } & $\frac{N}{N}$ & \multicolumn{2}{|c|}{$\begin{array}{l}\stackrel{*}{\sim} \\
\stackrel{N}{\sim}\end{array}$} & \multirow{2}{*}{ 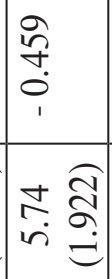 } & \multicolumn{2}{|l|}{$\begin{array}{l}\text { fa } \\
\stackrel{0}{0} \\
\dot{1}\end{array}$} & $\begin{array}{l}\delta \\
\infty \\
\infty \\
0\end{array}$ & \multirow{2}{*}{ 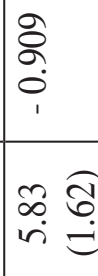 } \\
\hline & & & & 尚 & $\begin{array}{l}\widetilde{F} \\
+ \\
\dot{e} \\
\dot{e}\end{array}$ & $\stackrel{?}{\stackrel{?}{r}}$ & & 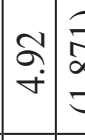 & 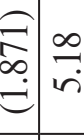 & $\mid$\begin{tabular}{l}
2 \\
$\infty$ \\
$\infty$ \\
\hdashline \\
\hdashline
\end{tabular} & & $\begin{array}{ll}\infty & \\
\infty & \\
\dot{n}\end{array}$ & 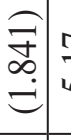 & 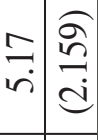 & \\
\hline & & 羃 & 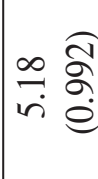 & 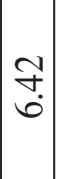 & 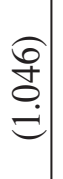 & ठิ. & 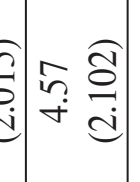 & 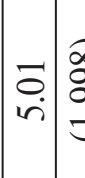 & 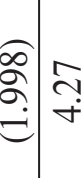 & 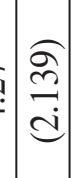 & $\begin{array}{ll}\dot{\sigma} & \widehat{\sigma} \\
\dot{\imath} & =\end{array}$ & $\begin{array}{l}\text { ํ. } \\
\dot{v}\end{array}$ & 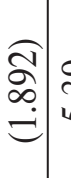 & 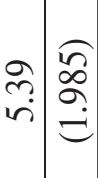 & 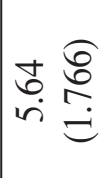 \\
\hline & & 窇 & $\frac{*}{\sigma}$ & 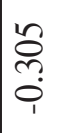 & & 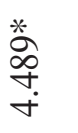 & $\stackrel{\Xi}{\varrho}$ & 志 & 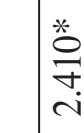 & & 훙. & $\begin{array}{l}\tilde{y} \\
\stackrel{n}{9}\end{array}$ & & 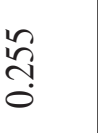 & $\stackrel{*}{\stackrel{*}{F}}$ \\
\hline & $\begin{array}{l}\stackrel{\Xi}{\Xi} \\
\stackrel{\Xi}{\Xi}\end{array}$ & 雚 & 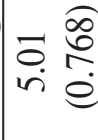 & 光 & $\begin{array}{c}\widehat{\widehat{\Theta}} \\
\stackrel{e}{e}\end{array}$ & $\underset{c}{\stackrel{2}{c}}$ & 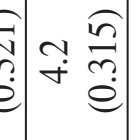 & 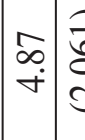 & \begin{tabular}{l|l}
$\widehat{\overline{0}}$ & \multirow{2}{0}{} \\
$\dot{d}$ & \multirow{2}{*}{}
\end{tabular} & 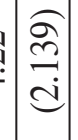 & 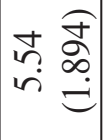 & $\begin{array}{l}\infty \\
\infty \\
\dot{r}\end{array}$ & 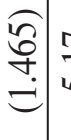 & 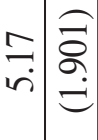 & 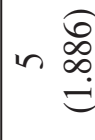 \\
\hline & & 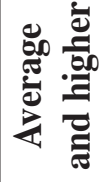 & 守 & $\underset{0}{\infty}$ & 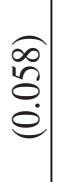 & $=\frac{7}{s}$ & 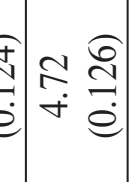 & aे & 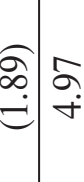 & 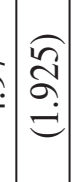 & 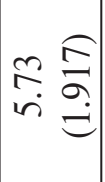 & 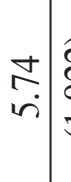 & 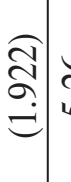 & 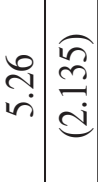 & 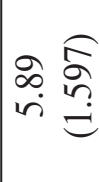 \\
\hline & & 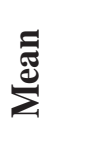 & $\begin{array}{l}\hat{n} \\
\text { in } \\
\text { in }\end{array}$ & $\stackrel{\infty}{+}$ & $\begin{array}{l}\hat{\sigma} \\
\hat{\sigma}\end{array}$ & 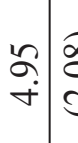 & 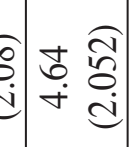 & 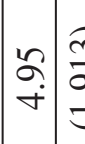 & 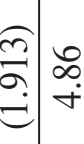 & 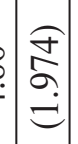 & in $\frac{\widehat{\tau}}{\sigma}$ & $\begin{array}{ll}n \\
i n\end{array}$ & 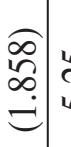 & 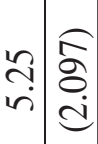 & 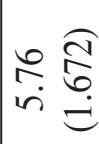 \\
\hline & & 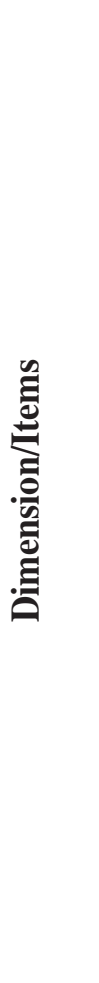 & 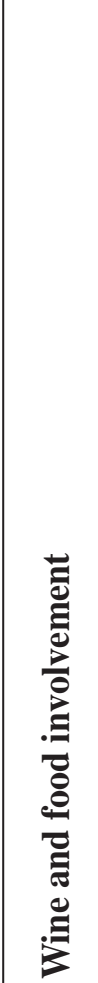 & 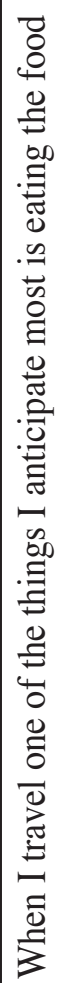 & & 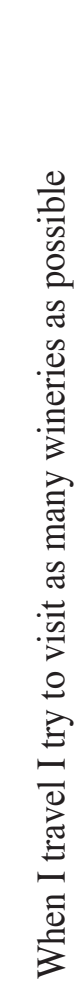 & 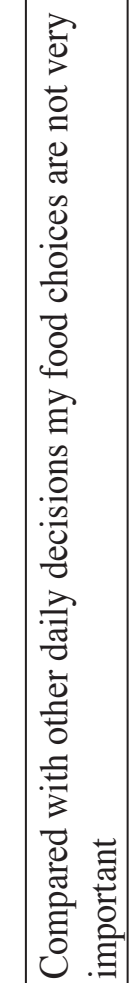 & 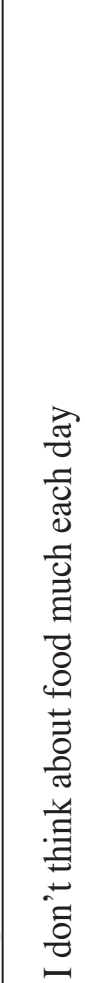 & & 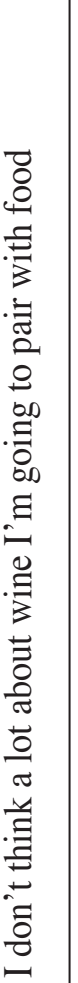 & 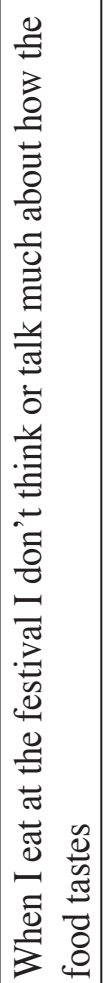 & 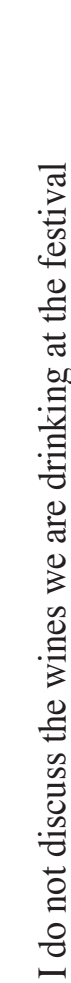 & 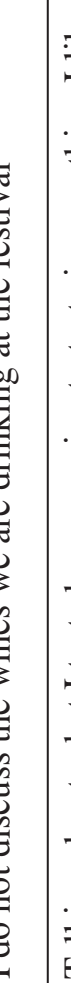 & 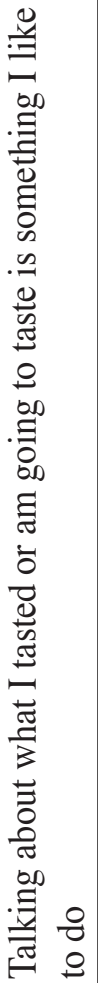 & 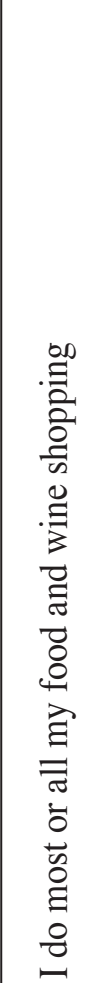 \\
\hline
\end{tabular}




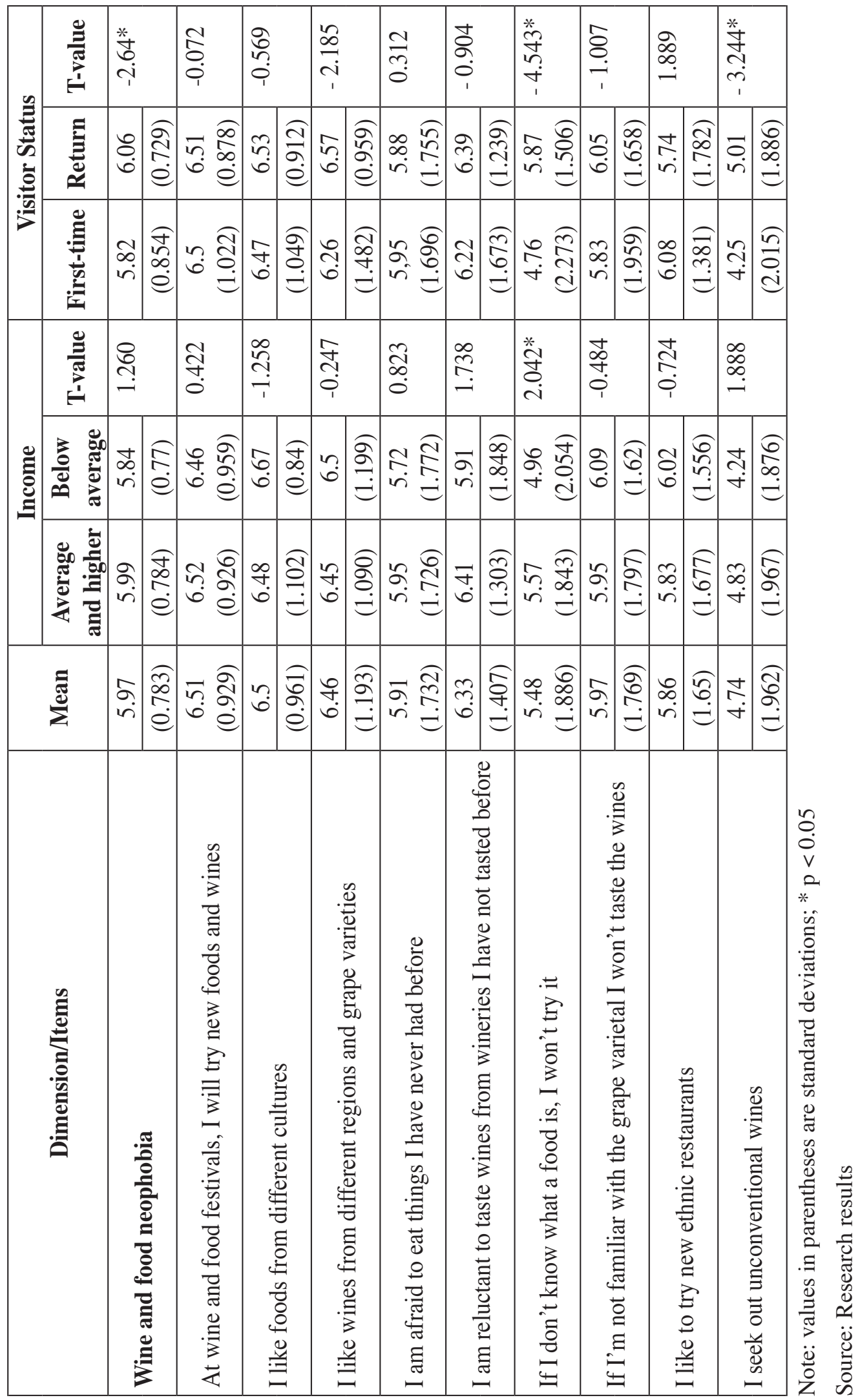


As shown in Table 3, visitors of the wine and food festival have a relatively high level of involvement and a low level of neophobia (note: items for neophobia construct were recoded in the opposite direction). Among neophobia construct items, the highest average score was given to the item "At food and wine festivals I will try new foods and wines", while the lowest mean score was given to "I seek out unconventional wines". In the wine and food involvement construct the highest mean score was given to the item "When I travel one of the things I anticipate most is eating the food there", while the item "Compared with other daily decisions my food choices are not very important" was given the lowest mean score. Regarding the income levels of visitors, significant differences were found in mean scores for involvement as visitors with average and higher income levels had a significantly higher mean score for the construct which confirms $\mathrm{H} 5 \mathrm{c}$ hypothesis that that wine festival visitors have significantly different level of wine and food involvement in regards to their income level. The neophobia construct did not have a significantly higher mean score as only one item showed a significant difference ("If I don't know what the food is, I won't eat it") so we can reject the H6c hypothesis that wine festival visitors have significantly different level of wine and food neophobia in regards to their income level. Additionally, both constructs showed significant differences in mean scores given by the visitors, with repeat visitors having a significantly higher wine and food involvement and lower neophobia. Two items for each construct showed significant differences. For the neophobia construct they were: "I seek out unconventional wines" and "If I don't know what the food is I won't try it", while for involvement construct they were: "When I travel I try to visit as many wineries as possible" and "I don't think a lot about the wine I'm going to pair with food". Thus, we can confirm H5b and H6b hypothesis that festival visitors will have different levels of wine and food involvement and neophobia depending on are they first time or repeat visitors of the wine festival.

Even though certain items within the constructs did show significantly different mean scores, no significant differences were found in the mean scores of wine and food involvement and the neophobia constructs of male and female visitors of the festival. Items that showed significantly different mean scores for male and female visitors were "When I travel I try to visit as many wineries as possible" $(\mathrm{t}=3.428, \mathrm{df}=301, \mathrm{p}<0.05)$ with male visitors having the higher mean score and "When I eat at the festival I don't think about how the food tastes" ( $t=-2.021$, $\mathrm{df}=273.032, \mathrm{p}<0.05)$ with female visitors having the higher mean score. Both items were from the wine and food involvement construct. International visitors had significantly higher mean score for the items "If I don't know what the food is, I won't try it ( $\mathrm{t}=-2.631, \mathrm{df}=107.166, \mathrm{p}<0.05)$ and "I seek out unconventional wines" ( $\mathrm{t}=-2.586, \mathrm{df}=77.591, \mathrm{p}<0.05)$ from the neophobia construct, and a higher mean score in items "When I travel I try to visit as many wineries as possible" $(\mathrm{t}=-4.371, \mathrm{df}=88.089, \mathrm{p}<0.05)$ and "I don't think a lot about the wine I am go- 
ing to pair with food" ( $\mathrm{t}=-2.066, \mathrm{df}=302, \mathrm{p}<0.05)$ from the neophobia construct. Unemployed festival visitors had only one significantly higher score in an item from the involvement construct, namely "At food and wine festivals I will try new foods and wines" ( $\mathrm{t}=-2.402, \mathrm{df}=293,352, \mathrm{p}<0.05)$. Accordingly, we can reject the proposed H5a, H6a, H5d, H6d, H5e, H6e hypotheses that the level of wine and food involvement and neophobia will differ in regards to wine festival visitors' gender, nationality and employment.

Table 4.

\section{CORRELATIONS BETWEEN WINE AND FOOD PERSONALITY TRAITS, EXPERIENCE QUALITY, EXPERIENCE OUTCOMES}

\begin{tabular}{|l|c|c|c|c|c|c|c|}
\hline Dimension & $\begin{array}{c}\text { Environment } \\
\text { Experience }\end{array}$ & $\begin{array}{c}\text { Service } \\
\text { Providers } \\
\text { Experience }\end{array}$ & $\begin{array}{c}\text { Education } \\
\text { Experience }\end{array}$ & $\begin{array}{c}\text { Entertainment } \\
\text { Experience }\end{array}$ & $\begin{array}{c}\text { Functional } \\
\text { Benefits } \\
\text { Experience }\end{array}$ & Loyalty & Satisfaction \\
\hline $\begin{array}{l}\text { Wine \& Food } \\
\text { Involvement }\end{array}$ & .102 & $197^{* *}$ & .091 & $.254^{* *}$ & $.195^{* *}$ & $.263^{* *}$ & $.232^{* *}$ \\
\hline $\begin{array}{l}\text { Wine \& Food } \\
\text { Neophobia }\end{array}$ & $.309^{* *}$ & $.339^{* *}$ & $.236^{* *}$ & $357^{* *}$ & $.367^{* *}$ & $400^{* *}$ & $.413^{* *}$ \\
\hline
\end{tabular}

** significant at 0.01 level

Source: Research results

Table 4 shows significant correlations between wine and food involvement and neophobia constructs and experience quality constructs and experience outcomes. The neophobia construct shows a stronger relationship and significant correlations with all observed experience quality dimensions which confirms hypothesis $\mathrm{H} 2$ and all of the supporting hypotheses as significant correlation has been found between the construct and experience quality dimensions of environment $(\mathrm{r}=0.309, \mathrm{~N}=304, \mathrm{p}<0,01)$ which confirms H2b, education $(\mathrm{r}=0.236, \mathrm{~N}=304, \mathrm{p}$ $<0,01)$ which confirms H2a, service providers $(\mathrm{r}=0.339, \mathrm{~N}=304, \mathrm{p}<0,01)$ which confirms H2c, functional benefits ( $r=0.367, \mathrm{~N}=304, \mathrm{p}<0,01)$ which confirms $\mathrm{H} 2 \mathrm{~d}$ and entertainment $(r=0.357, \mathrm{~N}=304, \mathrm{p}<0,01)$ which confirms H2e. The involvement construct seems not to be correlated with the environment and education dimensions so we can reject hypotheses H1a and H1b but can confirm H1c, H1d, H1e hypotheses as involvement is significantly and positively correlated with service provider $(r=0.197, \mathrm{~N}=304, \mathrm{p}<0,01)$, functional benefits $(\mathrm{r}=0.195, \mathrm{~N}=304, \mathrm{p}<0,01)$ and entertainment $(r=0.254, N=304, p<0,01)$ experience dimensions. Hence, we can also confirm the proposed $\mathrm{H} 1$ hypothesis that wine and food involvement has 
a significant positive relationship with experience quality. Additionally, wine and food neophobia and involvement are correlated to the observed experience quality constructs in opposite directions as involvement is positively correlated and neophobia negatively correlated to the experience constructs due to reversed scoring of the construct items. Hence, a higher degree of wine and food involvement leads to higher perception of experience quality with regard to service providers, entertainment and functional benefits, while a lower degree of wine and food neophobia leads to higher perceptions of experience quality with regard to environment, service providers, education, entertainment and functional benefits experience constructs. In regard to the relationship of wine food personality traits and experience outcomes we can confirm hypotheses $\mathrm{H} 3$ and $\mathrm{H} 4$ as well as proposed supporting hypotheses as significant correlations exist between wine and food involvement and satisfaction $(r=0.263, \mathrm{~N}=304, \mathrm{p}<0,05)$ which confirms H3a and loyalty $(r=0.232, \mathrm{~N}=304, \mathrm{p}<0,05)$ which confirms H3b. Additionally, wine and food neophobia showed significant correlations with satisfaction $(r=0.413, N=304$, $\mathrm{p}<0,05)$ and loyalty $(\mathrm{r}=0.413, \mathrm{~N}=304, \mathrm{p}<0,05)$ which confirms $\mathrm{H} 4 \mathrm{a}$ and $\mathrm{H} 4 \mathrm{~b}$ respectively.

\section{Discussion}

This research aimed to measure the level of wine and food involvement and neophobia within the context of a wine festival. Results of the research are generally consistent with those of past research (Pliner and Hobden, 1992; Raudenbush and Frank, 1999; Bell and Marshall, 2003; Ritchey et al., 2003; Cohen and Avieli, 2004; Brown, Havitz and Getz 2006; ) in that visitors taking part in wine and food events and festivals have a tendency towards low wine and food neophobia and are more highly involved with wine and food.

With regard to the relationship of experience constructs and wine and food related personality traits, our results indicate that visitors' festival experiences within the framework of the 4Es are positively correlated with wine and food involvement and negatively correlated with wine and food neophobia, as hypothesized. To the best of the authors' knowledge, this is the first time a significant relationship between these constructs has been identified.

However, not all constructs within the experience economy framework were correlated to wine and food involvement, specifically "environment" and "education". This may stem from the fact that highly-involved festival visitors do not focus on the surroundings and esthetics of a festival but rather focus on the core offerings of wine and food. Previous research has also shown that consumers who 
are highly involved with wine are more educated and/or knowledgeable about the subject (Brown, Havitz and Getz 2006), so the often basic education one may experience during a food and wine festival, with regard to learning through communication with winemakers and wine lovers at the festival, is not as high on the list of memorable experiences for highly-involved festival visitors, as our results suggest.

Experience outcomes, namely the satisfaction and loyalty of festival visitors, are significantly correlated with levels of wine and food neophobia and involvement. This finding stands in contrast with that of Kim, Won and Eves (2010), who found no relationship between visitor involvement and satisfaction. The findings of other relationships are consistent with previous studies (Bell and Marshall, 2003; Cohen and Avieli, 2004; Brown, Havitz and Getz 2006), which have shown that personality traits related to food choice and satisfaction can predict the likelihood of future behavior. However, because significant differences were found for both personality traits levels with regard to return visitors compared to first-time visitors, the results point to a connection between wine and food related personality traits and loyalty that needs to be explored further.

While certain explored demographics such as gender, residency or employment did not show to have a significant effect on levels of food and wine involvement and neophobia, significant differences were found for the involvement construct with regard to visitors with higher income. This leads to the conclusion that income level will determine a person's involvement in all things wine and food, which in consistent with previous research by Brown, Havitz and Getz (2006). However, according to our results, higher income does not affect wine festival visitor inclination to new food experiences as no difference was found for the neophobia construct.

\section{Conclusion}

Wine festivals have become vital parts of the wine tourism experience and are slowly morphing into lifestyle experience events that bring exposure to winemakers and wineries as well as to regions and destinations.

The present research aimed to measure and compare visitors' food related personality traits, namely involvement and neophobia, and compare them with specific demographic characteristics of visitors to determine a possible relationship between observed personality traits, perceived experience quality and experience outcomes. Results show that a significant and positive relationship exists between wine and food involvement and experience quality as well as experience 
outcomes while a significant and negative relationship exists between wine and food neophobia, experience quality and experience outcomes. Hence, the study has significance as it integrates the two bodies of food research and hospitality and tourism research and, for the first time, identifies a significant relationship between wine and food personality traits and festival visitors' perceptions of experience quality. Therefore, wine and food involvement and neophobia can be added as considerable factors influencing experience, satisfaction and loyalty in hospitality and tourism research.

Marketers should take wine and food related personality traits into consideration when organizing wine and food events because visitors with low neophilic tendencies and high involvement represent loyal customers who will generate more revenue and contribute to reducing marketing costs. Also, an interesting application stems from the fact that visitors with lower income levels do not shy away from new food experiences but rather are not that involved for mostly financial reasons. Accordingly, certain marketing strategies and products could be developed to convert the market of lower income visitors as not all wine and food currently on the market is in the premium category.

This study has several limitations. It examines only a single event using a sample of mostly domestic visitors and hence has limited ability to generalize the results. Future research could look at the longitudinal data from the festival or compare results across countries to account for possible cultural differences. In addition, the present research takes into account only correlations between the constructs which are relatively small, so it would be necessary to test the relationship in a higher-order theoretical model to define paths of influence among the construct using structural equation modeling and also look at food related personality traits as mediating factors between perceptions of experience quality and experience outcomes. Additional motivations and personality traits could be explored as possible factors that influence experience quality and experience outcomes.

Acknowledgement - This paper is the result of the scientific project "New Approaches to Measuring Visitor Experience in the Tourist Destination", which is supported by the University of Rijeka (project ZP UNIRI 3/17). 


\section{References:}

Ajzen, I. (1991). The theory of planned behavior. Organizational Behavior and Human Decision Processes,50, 179-211.

Arvola, A., Lahteenmaki, L., and Tuorila, H. (1999). Predicting the intent to purchase unfamiliar and familiar cheeses, the effects of attitudes, expected liking and food neophobia. Appetite, 32 (1), 113-26.

Axelsen, M. and Swan, T. (2010). Designing festival experiences to influence visitors' perceptions, The case of a wine and food festival. Journal of Travel Research, 49(4) 1-15

Backstrom, K., and Johansson, U. (2006). Creating and consuming experiences in retail store environments, comparing retailer and consumer perspectives. Journal of Retailing and Consumer services, 13(6), 417-30.

Bagdare, S., \& Jain, R. (2013). Measuring retail customer experience. International Journal of Retail \& Distribution Management, 41(10), 790-804.

Barber, N., Taylor, C. and Deale, C. (2010). Wine tourism, environmental concerns and purchase intention. Journal of Travel and Tourism Marketing, 27(2), $146-65$.

Bell, R., and Marshall, D. (2003). The construct of food involvement in behavioral research, Scale development and validation. Appetite, 40(3), 235-44.

Berry, L., Carbone, P., and Haeckel, H. (2002). Managing the total customer experience. MIT Sloan Management Review, 43(3), 85-9.

Bolton, R., Gustafsson, A., Mc-Coll Kennedy, J., Sirianni, N., and Tse, D. (2014). Small details that make big differences, a radical approach to consumption experience as a firm's differentiating strategy. Journal of Service Management, 25(2), 253-74.

Brown, G., Havitz, M., Getz, D., 2006. Relationship between wine involvement and wine-related travel. Journal of Travel and Tourism Marketing 21 (1), 31-46.

Bruwer, J. (2003). South African wine routes, Some perspective on the wine tourism industry's structural dimensions and wine tourism product. Tourism Management, 24(4), 423-35.

Bruwer, J., \& Buller, C. (2013). Product involvement, brand loyalty, and countryof-origin brand preferences of Japanese wine consumers. Journal of wine research, 24(1), 38-58.

Carmichael, B. (2005). Understanding the wine tourism experience for winery visitors in the Niagara region, Ontario, Canada. Tourism Geographies, 7(2), 185-204. 
Chang, T. and Horng, S. (2010). Conceptualizing and measuring experience quality, the customer's perspective. The Service Industries Journal, 30(14), 2401-19.

Charters, S., \& Ali-Knight, J. (2000). Wine tourism-a thirst for knowledge? International Journal of Wine Marketing, 12(3), 70-80.

Charters, S., \& Ali-Knight, J. (2002). Who is the wine tourist? Tourism management, 23(3), 311-319.

Cohen, E. (1979). A phenomenology of tourist experiences. Sociology, 13(2), 179-201.

Cohen, E., and Avieli, N. (2004). Food in tourism, attraction and impediment. Annals of Tourism Research, 31(4), 755-78.

De Rojas, C., and Camarero, C. (2008). Visitors' experience, mood and satisfaction in a heritage context, Evidence from an interpretation center. Tourism Management, 29(3), 1-13.

Fernandes, T., \& Cruz, M. (2016). Dimensions and outcomes of experience quality in tourism: The case of Port wine cellars. Journal of Retailing and Consumer Services, 31, 371-379.

Furst, T., Connors, M., Bisogni, C., Sobal, J., and Falk, L. (1996). Food choice, a conceptual model of the process. Appetite, 26, 247-66.

Fountain, J., \& Charters, S. (2010). Generation Y as wine tourists: their expectations and experiences at the winery cellar door. Tourism and generation Y, 15(5), 47-57.

Frow, P., \& Payne, A. (2007). Towards the 'perfect' customer experience. Journal of Brand Management, 15(2), 89-101.

Galloway, G., Mitchell, R., Getz, D., Crouch, G., and Ong, B. (2008). Sensation seeking and the prediction of attitudes and behaviors of wine tourists. Tourism Management 29(5), 950-66.

Gentile, C., Spiller, S., and Noci, C. (2007). How to sustain the customer experience, an overview of experience components that co-create value with the customer. European Management Journal, 25(5), 395-410.

Getz, D. (2000). Explore Wine Tourism, Management, Development and Destinations. Tourism Management, 23(6), 641-3.

Getz, D., and Brown, G. (2006). Critical success factors for wine tourism regions, A demand analysis. Tourism Management, 27(1), 146-58.

Getz, D., \& Carlsen, J. (2008). Wine tourism among Generations X and Y. Turizam: međunarodni znanstveno-stručni časopis, 56(3), 257-269.

Gross, M. J., and Brown, G. (2006). Tourism experiences in a lifestyle destination setting, The roles of involvement and place attachment. Journal of Business Research, 59(6), 696-700. 
Hall, C.M., Sharples, L., Cambourne, B., Macionis, N., (2000). Wine tourism around the world. Oxford: Butterworth-Heinemann.

Han, H., \& Back, K. J. (2007). Assessing customers' emotional experiences influencing their satisfaction in the lodging industry. Journal of Travel \& Tourism Marketing, 23(1), 43-56.

Han, H., Back, K. J., \& Barrett, B. (2009). Influencing factors on restaurant customers' revisit intention: The roles of emotions and switching barriers. International journal of hospitality management, 28(4), 563-572.

Hjalager, A., and Corigliano, M. (2000). Food for tourists, determinants of an image. International Journal of Tourism Research, 2(4), 281-93.

Hosany, S., \& Witham, M. (2010). Dimensions of cruisers' experiences, satisfaction, and intention to recommend. Journal of Travel Research, 49(3), 351-364.

Jakkola, E., Helkkula, A., and Aarikka-Stenroos, L. (2015). Understanding and advancing service experience co-creation. Journal of Service Management, 26(2), 182-205.

Kenningham, T., Cooil, B., Aksoy, L., Andreassen, T., Weiner, J., (2007). The value of different customer satisfaction and loyalty metrics in predicting customer retention, recommendation and share-of-wallet. Management of Service Quality 17(4), 361-384

Khan, M.A. (1981). Evaluation of food selection patterns and preferences. CRC Critical Reviews in Food Science and Nutrition, 15, 129-53.

Kim, Y.G., Eves, A., and Scarles, C. (2009). Building a model of local food consumption on trips and holidays, a grounded theory approach. International Journal of Hospitality Management, 28(3), 423-31.

Kim, Y. G. Won S. B., and Eves, A. (2010). The relationships between food-related personality traits, satisfaction, and loyalty among visitors attending food events and festivals. International Journal of Hospitality Management, 29(2), 216-26.

Kim, S., Knutson, B., and Beck, J. (2011). Development and testing of the Consumer Experience Index (CEI). Managing Service Quality, 21(2), 112-32.

Klaus, P., and Maklan, S. (2012). EXQ, a multiple-item scale for assessing service experience Journal of Service Management, 23(1), 5-33.

Knutson, B. J., Beck, J. A., Kim, S. H., \& Cha, J. (2007). Identifying the dimensions of the experience construct. Journal of Hospitality \& Leisure Marketing, 15(3), 31-47.

Lee S., Bruwer J., and Song H.J. (2015). Experiential and involvement effects on the Korean wine tourist's decision-making process, Current Issues in Tourism, 20(12), 1-17. 
Lemke, F., Clark, M., \& Wilson, H. (2011). Customer experience quality: an exploration in business and consumer contexts using repertory grid technique. Journal of the Academy of Marketing Science, 39(6), 846-869.

Lu, L., Chi, C. G., \& Liu, Y. (2015). Authenticity, involvement, and image: Evaluating tourist experiences at historic districts. Tourism Management, 50, 85-96.

Naylor, G., Keiser, B., Baker, J., and Yorktown, E. (2008). Using transformational appeals to enhance the retail experience. Journal of Retailing, 84(1), 49-57

Mehmetoglu, M., \& Engen, M. (2011). Pine and Gilmore's concept of experience economy and its dimensions: An empirical examination in tourism. Journal of Quality Assurance in Hospitality \& Tourism, 12(4), 237-255.

Manthiou, A., Lee, S., Tang, L., \& Chiang, L. (2014). The experience economy approach to festival marketing: Vivid memory and attendee loyalty. Journal of Services Marketing, 28(1), 22-35.

Oh, H., Fiore, A. M., \& Jeong, M. (2007). Measuring the tourist experience using experience economy concepts. Journal of Travel Research, 46(2), 119-132.

Oliver, R. (1997). Satisfaction, A Behavioral Perspective on the Consumer. New York, McGraw- Hill.

Oliver, R., and Burke, R. (1999). Expectation processes in satisfaction formation, a field study. Journal of Service Research, 1(3), 196-214.

Pliner, P., and Hobden, K. (1992). Development of a scale to measure the trait of food neophobia in humans. Appetite, 19(2), 105-20.

Pine II, B., and Gilmore, J. (1998). Welcome to the experience economy. Harvard Business Review, 76(4), 97-105.

Pine, B. J., and Gilmore, J. H. (1999). The experience economy, Work is theatre and every business a stage. Boston, MA, Harvard Business School Press.

Poria, Y., Butler, R. and Airey, D. (2004). Links between tourists, heritage, and reasons for visiting heritage sites. Journal of Travel Research, 43(1), 19-28.

Quadri, D., and Fiore, A.M. (2013). Destination loyalty, Effects of wine tourists' experiences, memories and satisfaction experiences. Tourism and Hospitality Research, 13(1), 47 - 62.

Quan, S., and Wang, N. (2004). Towards a structural model of the tourist experience, An illustration from food experiences in tourism. Tourism Management, 25(3), 297-305.

Raudenbush, B., and Frank, R.A. (1999). Assessing food neophobia, the role of stimulus familiarity. Appetite, 32(2), 261-71.

Ritchey, P.N., Frank, R.A., Hursti, U., and Tuorila, H. (2003). Validation and crossnational comparison of the food neophobia scale (FNS) using confirmatory factor analysis. Appetite, 40(2), 163-73. 
Sandstrom, S., Edvardsson, B., Kristensson, P., and Magnusson, P. (2008). Valuein-use through service experience. Management of Service Quality, 18(2), $112-26$.

Schmitt, B. (1999. Experiential marketing. Journal of Marketing Management 15(1-3), 56-67.

Shaw, C. and Ivens, J. (2005). Building Great Customer Experiences. MacMillan, New York

Slåtten, T., Mehmetoglu, M., Svensson, G., \& Sværi, S. (2009). Atmospheric experiences that emotionally touch customers: a case study from a winter park. Managing Service Quality: An International Journal, 19(6), 721-746.

Sparks, B. (2007). Planning a wine tourism vacation? Factors that help to predict tourist behavioral intentions. Tourism Management, 28(5), 1180-92.

Stamboulis, Y., \& Skayannis, P. (2003). Innovation strategies and technology for experience-based tourism. Tourism management, 24(1), 35-43.

Sternberg, E. (1997). The iconography of the tourism experience. Annals of Tourism Research 24(4), 951- 69.

Steyn, S., Saayman, M., and Nienaber, A. (2004). The impact of tourist and travel activities on facets of psychological well-being. South African Journal for Research in Sport, Physical Education and Recreation, 26(1), 97-106.

Taylor, R., and Shanka, T. (2007). Importance of wine festival characteristics in determining first-time and repeat visitors' festival experience. In Proceedings of the Australian and New Zealand Marketing Academy conference, 58-63. University of Otago, North Dunedin.

Treloar, P., and Hall, C. M. (2008). Tasting fees and the youth market. Revista Brasileira de Pesquisa em Turismo, 2(2), 113-27

Tung, V. W. S., \& Ritchie, J. B. (2011). Exploring the essence of memorable tourism experiences. Annals of tourism research, 38(4), 1367-1386.

Tuorila, H., Meiselman, H.L., Bell, R., Cardello, A.V., and Johnson, W. (1994). Role of sensory and cognitive information in the enhancement of certainty and liking for novel and familiar foods. Appetite, 23, 231-46.

Uriely, N. (2005). The tourist experience, Conceptual developments. Annals of Tourism Research, 32(1), 199-216.

Urry J (1995) Consuming Places. London and New York: Routledge.

Volo, S., 2009. Conceptualizing experience: a tourist-based approach. Journal of Hospitality Marketing and Management 18, 111-126.

Walls, A. R. (2013). A cross-sectional examination of hotel consumer experience and relative effects on consumer values. International Journal of Hospitality Management, 32, 179-192. 
Williams, P. W., \& Kelly, J. (2001). Cultural wine tourists: Product development considerations for British Columbia's resident wine tourism market. International Journal of Wine Marketing, 13(3), 59-76.

Yuan, J., Cai, L. A., Morrison, A. M., and Linton, S. (2005). An analysis of wine festival attendees' motivations, A synergy of wine, travel and special events? Journal of Vacation Marketing, 11(1), 41-58.

\title{
TKO SU POSJETITELJI FESTIVALA HRANE I VINA? EKSPLORATORNO ISTRAŽIVANJE
}

\author{
Sažetak
}

Organiziranje vinskih festivala predstavlja jedinstvenu priliku vinskim destinacijama da posjetiteljima ponude širok raspon doživljaja koji se znatno razlikuju od njihovog svakodnevnog života i na određeni način predstavljaju najbolji način za pružanje doživljaja u vinskom turizmu. Cilj ovog istraživanja je izmjeriti obilježja ličnosti posjetitelja vezane uz hranu i vino, specifično razinu uključenosti i neofobije, te istražiti njihovu povezanost s dimenzijama kvalitete doživljaja festivala (okruženje, učenje, usluga, direktne koristi, zabava) i ishodima kvalitete doživljaja (zadovoljstvo, vjernost). Također, istraživanje ima za cilj usporediti razine uključenosti i neofobije posjetitelja u odnosu na njihova demografska obilježja (spol, razina prihoda, status posjetitelja, zaposlenje, mjesto boravka). Podaci su prikupljeni tijekom održavanja VinoCOM festivala 24. i 25. studenog 2017. u Zagrebu korištenjem anketnog upitnika. Metodama deskriptivne i bivarijatne statističke analize analizirani su prikupljeni podaci. Dobiveni rezultati pokazuju značajan i pozitivan odnos između uključenosti vina i hrane te kvalitete iskustva i iskustvenih ishoda. Istovremeno je potvrđena negativna veza između vina i prehrambene neofobije, iskustva kvalitete $\mathrm{i}$ ishoda iskustva.

Ključne riječi: vinski turizam, vinski festival, kvaliteta doživljaja, posjetitelji festivala, zadovoljstvo posjetitelja festivala 